\title{
In Whose Interest? Gender and Mass-Elite Priority Congruence in Sub-Saharan Africa
}

\section{Amanda Clayton', Cecilia Josefsson' ${ }^{2}$ (D), Robert Mattes ${ }^{3}$, and Shaheen Mozaffar ${ }^{4}$}

\begin{abstract}
Do men and women representatives hold different legislative priorities? Do these priorities align with citizens who share their gender? Whereas substantive representation theorists suggest legislators' priorities should align with their cogender constituents, Downsian-based theories suggest no role for gender. We test these differing expectations through a new originally collected survey data set of more than 800 parliamentarians and data from more than 19,000 citizens from 17 sub-Saharan African countries. We find that whereas parliamentarians prioritize similar issues as citizens in general, important gender differences also emerge. Women representatives and women citizens are significantly more likely to prioritize poverty reduction, health care, and women's rights, whereas men representatives and men citizens tend to prioritize infrastructure projects. Examining variation in congruence between countries, we find that parliamentarians' and cogender citizens' priorities are most similar where democratic institutions are strongest. These results provide robust new evidence and insight into how and when legislator identity affects the representative process.
\end{abstract}

\footnotetext{
'Vanderbilt University, Nashville, TN, USA

2Uppsala University, Sweden

${ }^{3}$ University of Strathclyde, Glasgow, Scotland

${ }^{4}$ Bridgewater State University, MA, USA
}

\section{Corresponding Author:}

Amanda Clayton, Department of Political Science, Vanderbilt University, 230 Appleton Place, Nashville, TN 37240-270I, USA.

Email: amanda.clayton@vanderbit.edu 


\section{Keywords}

gender, sexuality and politics; representation and electoral systems; African politics

\section{Introduction}

The rising number of women in positions of political power has been one of the most significant global trends in representative democracy in the last two decades. Women's presence in national parliaments has nearly doubled between 1997 and 2017, moving from 12\% of national legislative seats in a single or lower house to $23.6 \%$ during this period (International Institute for Electoral Democracy and Assistance [IDEA], 2017). As women's numbers in legislative bodies continue to grow, both scholarly and public attention has focused on the following question: under what circumstances does women's increased presence in political decision making (descriptive representation) lead to legislative outcomes that benefit women as a group and reflect women's political priorities (substantive representation)? Here, we ask important foregrounding questions to this line of research:

Research Question 1: Do elected representatives share the same legislative priorities as their cogender citizens?

Research Question 2: Does the congruence of gendered political priorities vary by legislative context, such as the degree of democratic openness or the number of descriptive representatives?

A great deal of empirical work seeks to address whether and how women legislators represent women's interests by, for instance, examining whether women legislators vote for and introduce bills that promote women's interests, such as combating violence against women or advancing women's reproductive rights (Swers, 2002; Taylor-Robinson \& Heath, 2003) or whether women legislators are more likely than their male colleagues to see women citizens as a distinct constituent group (Childs, 2002). Additional work uses legislator surveys to examine whether women parliamentarians hold more gender egalitarian attitudes than their male colleagues (Campbell, Childs, \& Lovenduski, 2010; Lovenduski \& Norris, 2003). Yet, less empirical work has examined how women's presence affects which sorts of issues are prioritized across the legislative spectrum, beyond issues directly related to women's interests.

We expand on the few studies that have taken this approach at the elite level in advanced Western democracies (Norris, 1996; Tremblay, 1998; 
Wängnerud, 2000) and in Latin America (Schwindt-Bayer, 2006). Our substantial geographic scope-17 countries in sub-Saharan Africa-allows the most comprehensive study to date on gender differences in representatives' priorities - and, importantly, allows us to examine variation in priority congruence across parliamentary features. Furthermore, we theorize and test empirically how gender differences in members of parliament (MP) priorities align with citizens who share their gender. Despite the centrality of descriptive characteristics and the congruence of political priorities to the concept of substantive representation, studies examining gender differences in issue salience at both the mass and elite levels are surprisingly scarce. Only Wängnerud (2000) and Griffin, Newman, and Wolbrecht (2012) analyze both MPs' and citizens' gender-specific priorities or preferences in Sweden and the United States, respectively. Yet, neither of these studies examines how MPs' gender-specific priorities across all legislative issues align with those held by citizens.

To our knowledge, ours is the first cross-national attempt to explicitly examine how gender affects the extent to which MPs' policy priorities converge across all issue domains - not just women's rights - with those of citizens. This line of research is imperative, as the assumption of shared priorities often forms the basis of many subsequent questions on gender and substantive representation; for example, whether and how women legislators advocate for legislative issues prioritized by women. These types of questions first necessitate assessing whether and under what circumstances descriptive representatives express gender-specific political priorities that align with those held by citizens.

Moreover, whereas feminist political theorists place great importance on women's presence in political decision making, arguing that women bring into politics a different set of values, experiences, and expertise (Phillips, 1995 , p. 65), most work on mass-elite priority congruence neglects the role of legislator gender. Rather, this latter vein of research generally argues that political elites will have electoral incentives to appeal to a broad array of constituents as well as party platforms, making other features of the electoral process more salient than gender as legislators form priorities (Downs, 1957; Jones \& Baumgartner, 2004). These two bodies of work, then, produce contradicting expectations, with the former expecting gender differences in legislators' priorities that reflect gender differences among constituents and the latter expecting no gender differences in legislators' priorities.

We test these contradicting expectations with new data from sub-Saharan Africa, a particularly salient region given the rapid increase in women's presence in national legislatures over the last 15 years. Women have achieved more than $40 \%$ representation in six African legislatures, some of the highest 
rates in the world (International IDEA, 2017). Whereas a rich body of work has examined the impact of women's presence on other aspects of substantive representation on the subcontinent, such as legislative gains for women (Bauer \& Britton, 2006; Goetz \& Hassim, 2003), debate participation (Atanga, 2010; Clayton, Josefsson, \& Wang, 2017), and postconflict reconstruction (Tripp, 2015), to date no work has systematically examined whether MPs express gender-specific political priorities and whether these priorities reflect similar gender differences among citizens.

Furthermore, African cases provided a relatively stringent test for theories of gender and substantive representation. African parties and party systems are typically described as clientelistic and ethnically based rather than embodying a representative process based on strong programmatic policy differences (see, for example, Ichino \& Nathan, 2013; Posner, 2005). Examining whether and when representatives share similar legislative priorities as citizens generally-and with cogender citizens in particular-will reveal whether African parliaments are operating in broadly representative and programmatic ways that have been previously overlooked. Furthermore, examining variation in priority congruence between African parliaments will reveal how the institutions that govern MP selection might constrain MPs from expressing gender-specific policy priorities.

We present three main findings. First, using original surveys of more than 800 elected parliamentarians in 17 geographically and politically diverse countries on the African subcontinent, we find that women MPs give higher prioritization than their male colleagues to issues related to poverty alleviation, health care, and women's rights, whereas men MPs prioritize infrastructure projects to a greater degree than women MPs. Second, relying on survey data from more than 19,000 citizens from the same 17-country sample, we find that whereas men and women, both legislators and citizens, generally prioritize similar issues, the gender differences that we observe among MPs correspond closely in size and substance with gender differences observed among citizens.

Third, we find considerable variation on the extent to which mass-elite gender gaps are aligned across countries. Although our country-level variation is limited given our 17-country sample, we offer a preliminary exploration of country-level differences that may explain when parliamentarians' priorities will align with their cogender constituents. We find that parliamentarians' and citizens' gender-specific priorities are most similar in more democratic countries and countries with stronger opposition parties - measured both through the number of effective parties and the share of legislative seats held by the opposition. We find that these differences are driven by MPs, who express more gender-specific priorities when democratic institutions are strongest. 


\section{Identifying Gendered Priorities}

In their influential volume, Franceschet, Krook, and Piscopo (2012) describe research on women's substantive representation as asking "whether women seek and are able to promote women's issues once they are elected to political office ... [and] whether women pursue alternative political objectives to those of men" (p. 8). One of the major challenges, then, in studying women's and men's substantive representation first lies in defining and measuring the content of gender-specific interests, issues, and priorities. Gender and politics scholars commonly conduct this line of research by first specifying women's interests a priori through issues that disproportionally affect women's welfare, such as investments in maternal health and combating domestic violence (Beckwith, 2014; Clayton et al., 2017) or issues related to women's traditional roles, such as investments in child and family health (Miller, 2008; Swiss, Fallon, \& Burgos, 2012). However, legislation (or other legislative work) that directly affects women's welfare or social roles makes up a very small proportion of parliamentary work.

Investigating gender differences across legislative priorities allows a broader understanding of the role legislator gender plays in the process of substantive representation. This approach also allows us to examine genderspecific priorities of both women and men. As the historically excluded group, most research has focused on whether women act for women, but understanding whether and how men also act for men is a crucial and often unexplored component of gender and substantive representation.

Another major challenge in measuring the link between descriptive and substantive representation, particularly in African cases, lies in the difficulty in assessing legislators' political priorities. Unlike parliaments in other world regions, particularly Latin America, where bill introduction or cosponsorship provides a good measure of legislator interests (e.g., Franceschet \& Piscopo, 2008; Taylor-Robinson \& Heath, 2003), most legislation in African parliaments is introduced through ministries (Kang, 2015; Thomas \& Sissokho, 2005, p. 9). ${ }^{1}$ Rather than deducing priorities from legislative behavior, survey data from the African Legislatures Project (ALP) and the Afrobarometer allow us to measure expressed political priorities through identical questions asked to African MPs and constituents in their respective countries. We argue that priority alignment is a necessary first condition for the process of substantive representation to occur - and one that has yet to be rigorously empirically established, particularly in cases outside of Western democracies.

As another challenge in measuring gender-specific priorities, we acknowledge that women's identities are multiple and constituted not only by gender but also by other identities, such as partisanship, class, ethnicity, and religion 
among many others, leading women even in the same communities to disagree on which political issues deserve prioritization (Celis \& Childs, 2012; Celis, Childs, Kantola, \& Krook, 2008). Less empirical research has explored men's gender-specific priorities; yet, men are also a heterogeneous group with diverse identities and interests, and the priorities of certain groups of men are also likely overlooked in the representative process (Murray, 2014). Collecting responses from a nationally representative sample of respondents allows us to assess rather than assume how men and women form and articulate political priorities, an approach that is both sensitive to citizens' multiple identities and avoids essentializing gender-specific priorities.

\section{Gender and Issue Prioritization: Theory and Expectations}

The role of legislator gender in the formation of political priorities presents an important theoretical puzzle, as different theories of representation produce contradicting expectations. We hypothesize there are three competing ways in which MP gender may affect priority alignment: that men and women MPs hold different priorities that align with citizens who share their gender, that MPs express no differences in issue prioritization, or that women and men MPs hold similar priorities that both align with priorities expressed by men citizens. We elaborate on each in turn.

\section{Hypothesis I: MPs Prioritize Issues Prioritized by Cogender}

\section{Citizens}

Our fist hypothesis is that men and women MPs hold different legislative priorities in ways that align with those held by citizens. This hypothesis is rooted in classic theories of gender and substantive representation. Normative theorists have attached great importance to women's presence in political bodies, arguing that women legislators are often better positioned and more motivated to represent interests and priorities specific to women citizens (Mansbridge, 1999). This may occur for several reasons. First, representatives may have similar priorities as their cogender constituents based on shared social experiences by gender, leading to diverging perspectives on the salience of various political issues (Phillips, 1995; Young, 2000). Because both women and men MPs have had to personally navigate gendered expectations and social roles, they may share similar priorities as citizens who share their gender based on similar internally held beliefs. Second, women representatives in particular may feel a mandate to act for the specific interests of women citizens because 


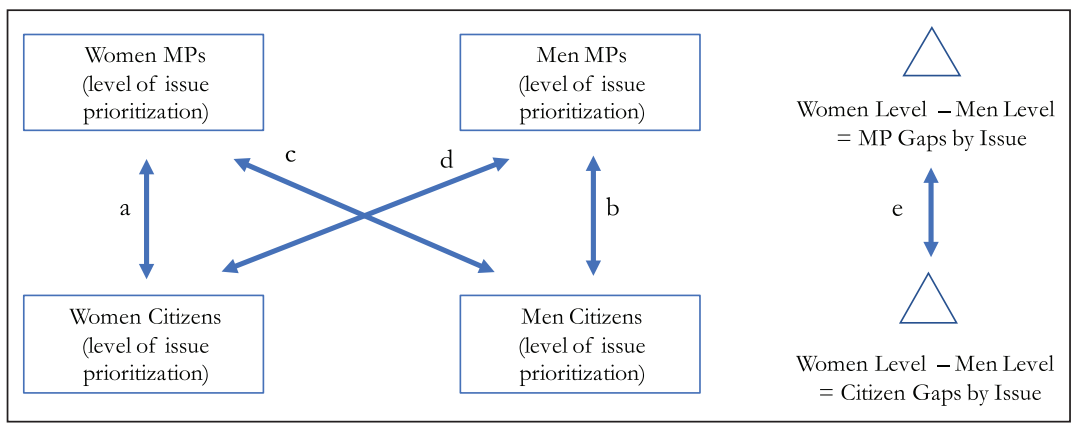

Figure I. Quantities of interest.

$M P=$ member of parliament.

their group has historically been excluded from positions of power (Franceschet $\&$ Piscopo, 2008). These two motivations relate specifically to how MPs form priorities in their role as trustee. But it is also possible that gender differences in MP priorities form based on differences in MP responsiveness. If citizens are more likely to engage with cogender representatives (Barnes \& Burchard, 2013), MPs may be more aware of the priorities of citizens who share their gender. Rather than internally held beliefs, then, legislators may be more responsive to cogender constituents because they have been more exposed to the needs of their gender-specific group.

Whether gender differences emerge because of MPs' differences in internally held priorities or based on gendered patterns of MP responsiveness, we should observe the following: First, we should observe the women MPs' priorities are more aligned with women citizens than with men citizens. Similarly, men MPs' priorities should be more closely aligned with men citizens than women citizens. We visualize these quantities of interest in Figure 1. The first implication of Hypothesis 1 implies that the correlational relationship depicted by arrow $a$ is greater than the relationship depicted by arrow $c$, and the correlational relationship depicted by arrow $b$ is greater than the relationship depicted by arrow $d$.

A second implication suggests significant gender differences should emerge among MPs. We have no strong a priori expectations about which issue areas men or women MPs will selectively prioritize except for one domain: issues dealing explicitly with women's rights. If women MPs feel a mandate to represent women's interests - that is, policies that advance the status and well-being of women as a group - then we expect women MPs to prioritize issues related specifically to women's rights to a greater degree 
than men MPs. Women MPs may feel a particular mandate to promote women's rights because of gendered electoral rules that allowed them to come to power, which exist in several of our cases (see Franceschet \& Piscopo, 2008), because of pressure from women's rights groups in civil society that actively lobby and train women MPs in may African countries (Goetz \& Hassim, 2003; Tripp, Isabel, Joy, \& Alice, 2008), or due to internally held beliefs about promoting group interests. If women MPs feel an obligation to advance women's rights, they may even prioritize these issues to a greater degree than women citizens.

Finally, and perhaps most critically, theories of priority alignment suggest that gender gaps among MPs (upper triangle) should be positively correlated with gender gaps observed among citizens (lower triangle). That is, if women MPs prefer certain issues more than men MPs, we should observe that women citizens will prioritize the same issues and of a similar magnitude greater than men citizens.

We expand more on the empirical distinction between prioritization levels and prioritization gaps below, but here, we note an important theoretical distinction as it relates to substantive representation. Examining correlations in prioritization levels between MPs and cogender citizens tests for gendered patterns in issue salience, but does not account for the general importance of particular issues. When we examine correlations in gender differences (as depicted by arrow $e$ in Figure 1), we are measuring how gender affects MP prioritization after accounting for the fact that some issues (e.g., the economy) are generally more prioritized by all citizens than other issues (e.g., women's rights). Correlations in levels test whether gender significantly predicts priority alignment without taking general issue salience into account, whereas correlations in gaps reveal whether gender is significant at the margins, after accounting for baseline levels of salience. Our theory as it relates to priority alignment above suggests there will be differences in MPs' priorities that align with those held by citizens, but does not reveal whether these differences will be strong enough to affect correlations in overall levels of prioritization between MPs and cogender citizens. We have stronger expectations, then, related to the last implication of Hypothesis 1 (observed correlations in gender gaps) than the first implication (observed correlations in cogender priority levels).

\section{Hypothesis 2: Men and Women MPs Prioritize Similar Issues}

There are, of course, reasons to expect that men and women representatives will not differ in how they form priorities. Representatives typically realize the electoral benefits of appealing to a broad range of constituents for reelection, which may outweigh gender-specific priorities. This may be particularly 
pronounced in plurality-based electoral systems in which MPs are directly elected by a roughly equal number of men and women constituents, rather than being allowed to carve out a more niche ideological space on a party list. However in party-based systems, legislators may face more pressure to be loyal to party platforms than to articulate gender-specific priorities (Walsh, 2012b). In addition, particularly in African legislatures, other cross-cutting identities, such as ethnic or religious identity, may be more salient as both legislators and citizens form political priorities (Posner, 2005).

Two observable implications emerge from this second hypothesis. First, if electoral incentives, party discipline, or other identity cleavages trump gendered priorities, we expect no systematic gender differences in issue prioritization between men and women MPs. Second, we should observe that men MPs and women MPs have similar levels of issue prioritization as both men and women citizens. In Figure 1, this implies that the correlational relationship indicated by arrow $a$ should be equal to the relationship indicated by arrow $c$ - and similarly, the relationship indicated by arrow $b$ should be equal to the correlation depicted by arrow $d$.

\section{Hypothesis 3: Men and Women MPs Prioritize Issues Prioritized by Men Citizens}

Finally, it is possible that women MPs see the benefit of adopting issues prioritized by men in male-dominated institutions. If men politicians have priorities specific to their gender, women MPs may enter parliaments in which legislative priorities are already defined. Because women are more likely to be political newcomers, they may have incentives to adapt to existing political norms that have already coalesced around men's priorities to appear as more serious or capable politicians (Kerevel \& Atkeson, 2013). These dynamics may be particularly pronounced under proportional representation systems in which MPs are more accountable to party elites to maintain their positions on party lists than to gender-balanced constituencies and pressure from civil society groups for reelection. In such circumstances, we expect both men and women MPs to prioritize issues expressed by men citizens. In our 17-country sample, men citizen respondents also self-report slightly higher voter turnout rates than women respondents $(73 \%$ vs. $67 \%)$, which could incentivize both men and women MPs to be more responsive to men's gender-specific priorities. Similar to our second hypothesis, this hypothesis also implies no gender differences will emerge in MPs' priorities. Distinct from the second hypothesis, however, here, we should also observe that women MPs' priorities are more closely correlated with levels expressed by men citizens than by women citizens. Returning to Figure 1, this implies the 
correlational relationships depicted by arrow $c$ should be greater than the relationship depicted by arrow $a$.

\section{Data and Method}

\section{Assessing Citizens' and MPs' Political Priorities}

We use original data we collected through the African Legislatures Project a research effort initiated by the Center for Social Science Research at University of Cape Town (Barkan, Mattes, Mozaffar, \& Smiddy, 2010). ALP conducted MP surveys in 17 countries, which cover more than half of the subcontinent's population, and were selected specifically because they also host Afrobarometer public opinion surveys. These data offer an excellent opportunity to test how and when legislator identity affects the representative process. First, recent research presents evidence of gender gaps in policy priorities among citizens, which vary in size and substance across African cases (Gottlieb, Grossman, \& Robinson, 2016). This variation allows us to test whether and how country-specific gender differences in citizens' priorities map onto gender differences observed among MPs. Second, the 17 cases offer a rich range of institutional variation, including the differing use of gender quotas, differing electoral systems, and differing levels of ruling party dominance, allowing us to test whether and how our findings vary across national institutional features. Furthermore, women's parliamentary representation on the African subcontinent has doubled in the last 15 years and tripled in the last 25, although far from uniformly across legislatures. Currently, women's representation in single or lower houses on the subcontinent range from $61 \%$ in Rwanda to just below $6 \%$ in Nigeria. Assessing whether and how women's legislative priorities differ from those of men representatives has potential implications for the types of policies introduced, debated, and enacted by African legislatures.

Our 17-country sample is geographically representative of the subcontinent. We have four cases from francophone West Africa (Benin, Burkina Faso, Mali, and Senegal) as well as two Anglophone countries in the region (Ghana and Nigeria), seven cases from southern Africa (Botswana, Lesotho, Malawi, Mozambique, Namibia, South Africa, Zambia, and Zimbabwe), and three from east Africa (Kenya, Tanzania, and Uganda), with the latter two regions consisting of both former British and Portuguese colonies. Ten of the cases use plurality/majoritarian electoral systems, five use proportional representation systems, and two use mixed systems. Five countries (Mozambique, Senegal, South Africa, Tanzania, and Uganda) had either legislated or ruling party voluntary gender quotas at the parliamentary level at the time of the MP surveys. 
The ALP surveys were conducted between 2008 and 2012, and the Afrobarometer surveys were conducted in 2008 and 2009. In general, our sample of cases tend to score more favorably on indices of democracy and political rights than the average values for sub-Saharan Africa, although our sample contains important variation, including liberal democracies (Ghana, South Africa, Benin), electoral democracies (Malawi, Lesotho, Zambia), and hybrid and closed regimes (e.g., Uganda, Mozambique, Zimbabwe). It also contains countries with both one-party dominant party systems (e.g., South Africa, Botswana, Namibia) and competitive party systems where incumbents have been turned out of office at the ballot box (e.g., Benin, Ghana, Senegal). The cases also vary in legislative strength. For instance, whereas the Kenyan legislature in particular and to a lesser extent, the Ugandan legislature, have emerged as politically powerful institutions, legislatures in Benin and Ghana remain weak, despite operating in more democratic contexts (Barkan, 2009). Online Appendix Table A1 shows the representativeness of the 17 cases compared with average economic and political indicators across the subcontinent, including details on the electoral system, the number of effective parties in parliament, ruling party seat share, women's parliamentary representation, and district magnitude for each case.

A random sample of 50 lower house MPs was selected in most countries; 60 MPs were selected in Nigeria and 40 were selected in Benin and Botswana, because of legislature size. ${ }^{2}$ Across the 17 cases, the data include survey responses from $823 \mathrm{MPs}$, representing $25 \%$ of the total population of MPs across the 17 countries. Women MPs constitute $17.7 \%$ of our respondents $(n$ $=144$ ), similar to the $19.1 \%$ of the total parliamentary seats held by women in the 17 cases at the time of the surveys.

Because the ALP and Afrobarometer samples were drawn independently, the data allow us to examine issue priority congruence at the country level, but not at the constituency level. Studying priority alignment at the national level is pertinent for several reasons. First, our representative samples at both the citizen and MP levels should similarly aggregate diverse priorities that vary across constituencies. Second, we assume citizens' interests can be represented both by their own elected representatives as well as surrogate representatives from other districts (see Mansbridge, 2011; Weissberg, 1978). This may be particularly relevant for gendered patterns of issue prioritization, as the gender-specific priorities we identify - health, poverty, women's rights, and infrastructure - are issues that likely cross constituency boundaries.

In both the ALP and Afrobarometer surveys, respondents were asked, "In your opinion, what are the three most important problems facing this country that government should address?"3 Although the question was open ended, interviews had an extensive, precoded list of issues generated from previous 
surveys. Respondents could offer up to three responses, though they were not asked to rank them in prioritization. Thus, we are only interested in whether the issue was mentioned, or not. Following Gottlieb et al. (2016), we took the detailed coding categories assigned by ALP and Afrobarometer interviewers and recoded them into 11 broader substantive issue areas: poverty, agriculture, the economy, education, health, infrastructure, social rights, political rights, violence, water, and women's rights. The complete coding is listed in Online Appendix Table A2.

We begin by presenting descriptive statistics from both the MP and citizen surveys in Table 1. We list the percentage of men and women MPs and men and women citizens who select each issue as one of their top three political priorities across our 17-country sample. We order the issues by those most commonly listed by MPs. We also calculate the differences in the percentage of men and women who prioritize each issue among both citizens and MPs. A few initial observations emerge from Table 1. Examining general issue salience, we see that MPs and citizens tend to prioritize similar issues. At both the mass and elite levels, the economy emerges as the most commonly listed priority followed by issues related to combating poverty. Interestingly, political rights emerge as the next most frequently listed priority for MPs (the second most for men MPs), whereas this category ranks only ninth (out of 11) for citizens. MPs are also almost twice as likely as citizens to raise education as a top priority, but less than half as likely to list water access and infrastructure projects. We also see that women's rights appear more salient to women MPs than to either men or women citizens; indeed, women MPs are about 7 times more likely to list women's rights as a top priority than women citizens.

\section{Convergence in MPs' and Citizens' Levels of Prioritization}

We use the data presented in Table 1 to test the implications that emerge from our three hypotheses on the role of gender in mass-elite priority congruence. Our first hypothesis is that MPs prioritize the same issues as citizens who share their gender. We begin by examining the correlation of prioritization levels (the percent of citizens who report an issue as a top priority) between women MPs and women citizens and men MPs and men citizens. Whereas we do observe slightly higher correlations between MPs and cogender citizens compared with noncogender citizens, these differences are negligible. ${ }^{4}$ Indeed, we find that the general salience of particular issues is so pronounced, it is difficult to observe gender-specific patterns when we measure convergence in this way. To further investigate gender-specific priorities while taking general issue salience into account, we turn to an examination of gender differences in issue prioritization among MPs and among citizens. 
Table I. Percentage of MPs and Citizens Who List Each Issue as One of Their Top Three Political Priorities.

\begin{tabular}{|c|c|c|c|c|c|c|}
\hline & $\begin{array}{l}\text { Women } \\
\text { MPs }\end{array}$ & Men MPs & $\begin{array}{c}\text { Difference } \\
(S E)\end{array}$ & $\begin{array}{l}\text { Women } \\
\text { citizens }\end{array}$ & $\begin{array}{c}\text { Men } \\
\text { citizens }\end{array}$ & $\begin{array}{l}\text { Difference } \\
\qquad(S E)\end{array}$ \\
\hline Economy & 59.72 & 69.21 & $\begin{array}{l}-9.48 \\
(6.30)\end{array}$ & 69.21 & 71.26 & $\begin{array}{l}-2.05 \\
(0.96)\end{array}$ \\
\hline Poverty & 45.83 & 35.13 & $\begin{array}{l}10.71 \\
(4.99)\end{array}$ & 60.15 & 51.82 & $\begin{array}{c}8.33 \\
(0.10)\end{array}$ \\
\hline Political rights & 41.67 & 48.88 & $\begin{array}{l}-7.21 \\
(6.65)\end{array}$ & 12.68 & 15.29 & $\begin{array}{c}-2.61 \\
(0.53)\end{array}$ \\
\hline Education & 33.33 & 36.17 & $\begin{array}{l}-2.84 \\
(4.49)\end{array}$ & 20.43 & 20.32 & $\begin{array}{c}0.11 \\
(0.58)\end{array}$ \\
\hline Health & 29.86 & 23.62 & $\begin{array}{c}6.24 \\
(4.17)\end{array}$ & 32.86 & 32.57 & $\begin{array}{c}0.29 \\
(0.69)\end{array}$ \\
\hline Infrastructure & 20.13 & 25.71 & $\begin{array}{l}-5.57 \\
(3.98)\end{array}$ & 41.85 & 43.94 & $\begin{array}{c}-2.09 \\
(0.86)\end{array}$ \\
\hline Agriculture & 16.67 & 18.69 & $\begin{array}{l}-2.02 \\
(3.63)\end{array}$ & 23.35 & 26.37 & $\begin{array}{c}-3.02 \\
(0.68)\end{array}$ \\
\hline Violence & 14.58 & 14.80 & $\begin{array}{l}-0.22 \\
(3.28)\end{array}$ & 13.24 & 15.36 & $\begin{array}{c}-2.12 \\
(0.52)\end{array}$ \\
\hline Women's rights & 9.72 & 0.90 & $\begin{array}{c}8.83 \\
(2.50)\end{array}$ & 1.39 & 0.50 & $\begin{array}{c}0.89 \\
(0.14)\end{array}$ \\
\hline Water & 6.25 & 6.13 & $\begin{array}{c}0.12 \\
(2.44)\end{array}$ & 23.42 & 20.77 & $\begin{array}{c}2.65 \\
(0.60)\end{array}$ \\
\hline Social rights & 4.17 & 5.23 & $\begin{array}{r}-1.06 \\
(1.88)\end{array}$ & 1.42 & 1.82 & $\begin{array}{l}-0.40 \\
(0.18)\end{array}$ \\
\hline
\end{tabular}

Women MPs, $n=144$; men MPs, $n=669$. MP = member of parliament.

\section{Convergence in Gender Gaps in Prioritization}

Hypothesis 1 predicted significant gender differences among MPs, which would be similar in size and substance to gender differences among citizens. Hypotheses 2 and 3, however, predicted no gender differences among MPs. To assess gender gaps among both citizens and elites, we return to the descriptive statistics presented in Table 1. First, we observe that the direction of gender differences in issue prioritization - that is, whether an issue is more frequently listed by men or by women - is the same among both citizens and MPs in 10 out of the 11 issue areas. Women MPs and women citizens prioritize (albeit in some cases minimally) issues related to poverty alleviation, women's rights, water, and health, whereas men MPs and men citizens prioritize issues related 


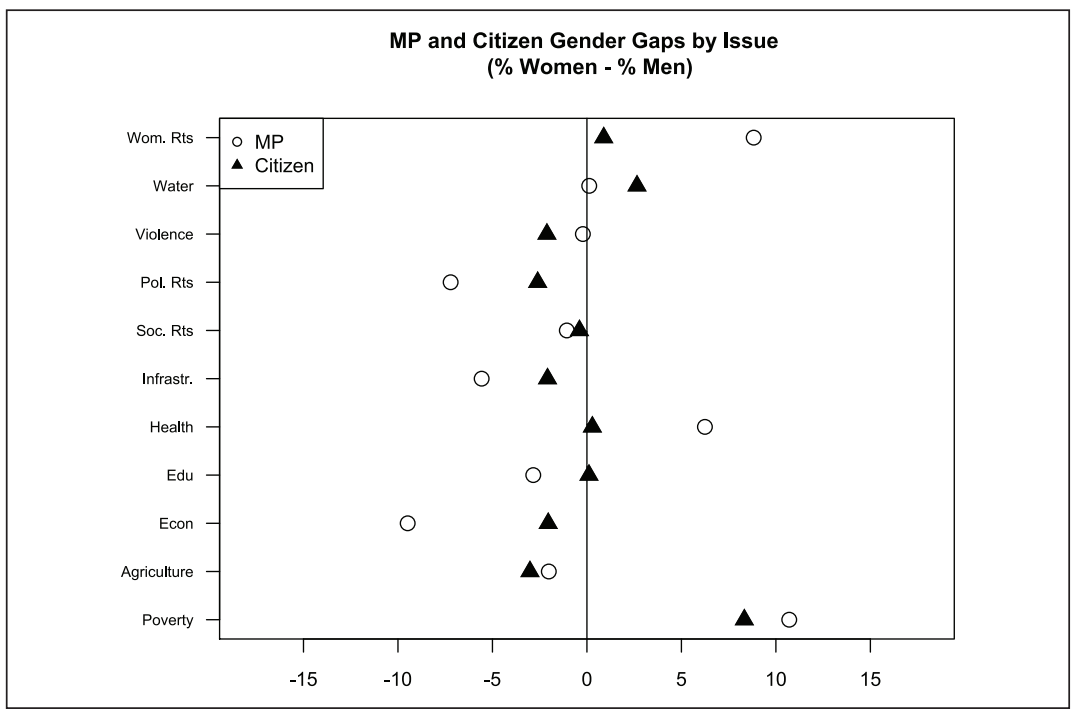

Figure 2. Gender gaps among MPs and citizens.

$M P=$ member of parliament.

to agriculture, the economy, infrastructure, social and political rights, and violence. Education is the only issue area for which gender differences between MPs and citizens do not go in the same direction-however, the gender gap among citizens ( $20.4 \%$ vs. $20.3 \%)$ is statistically indistinguishable from zero. ${ }^{5}$ Figure 2 visualizes the gender differences produced in Table 1 (the percentage of men who prioritize the issue subtracted from the percentage of women who prioritized the issue) for both citizens (filled triangles) and MPs (hollow circles).

To more systematically examine gender differences among MPs, we use a series of pooled seemingly unrelated ordinary least squares (OLS) regressions (SURs) to model MP-level predictors of policy prioritization by issue area. Following Gottlieb et al. (2016), we use SUR techniques to account for the fact that our outcome variables, measured by MP responses across issues from the same survey question, are not independent across responses. We take as our dependent variables responses to each issue area specified in Table $1 .{ }^{6}$ The coefficient estimates are identical to an OLS estimate of a linear probability model, as the explanatory variables are the same across outcomes. Our key explanatory variable is MP gender, and using self-reported data from the ALP survey, we also control for other dimensions of an MP's profile that may affect her issue prioritization, specifically: MP parliamentary tenure 
(years in office), whether the MP holds a ministerial position, whether the MP holds a party leadership position, and ruling party membership. All models include country fixed effects to account for all country-specific variables, including issue salience, which varies by country. Descriptive statistics for MP covariates by gender are listed in Online Appendix Table A2. Table 2 displays the SUR regression results.

We find that women MPs are more likely to prioritize policies related to poverty alleviation and women's rights, which reach conventional significance levels $(p \leq 0.05)$, as well as evidence that health is a women-preferred policy area $(p=.08) .{ }^{7}$ Men MPs, however, are significantly more likely to list infrastructure projects as a top political priority. We also note that, although not the focus of this study, members of the ruling party are significantly more likely to list the economy as a top priority, perhaps because they are viewed by their electorates as more responsible for economic performance. Ruling party MPs are also significantly less likely to list political rights as a legislative priority, including issues related to corruption, limits on the executive, and democratic openness.

We do not devote much space here to modeling gender gaps among citizens, as this is already done thoroughly in Gottlieb et al. (2016), but we do use Afrobarometer data to run basic SUR models with country fixed effects to assess gender differences among citizens within our 17-country sample. Tables 2 and 3 again indicate that descriptively (i.e., based on coefficient sign), gendered priorities at the citizen level align with those calculated at the MP level in 10 of the 11 issue areas. We find that women citizens, similar to women legislators, are significantly more likely to prioritize women's rights and poverty alleviation, whereas men citizens, like men representatives, prioritize infrastructure projects. We find that women citizens prioritize investments in the water supply, whereas there is no statistical difference at the MP level, and women MPs prioritize public health, whereas there is no statistical difference at the citizen level. We also observe that men citizens are significantly more likely to list agriculture, the economy, political rights, social rights, and violence than women citizens, and whereas men MPs are also more likely to prioritize each of these areas, these results do not reach statistical significance at the MP level. There appear to be no significant gender differences in the prioritization of education among either MPs or citizens.

In sum, we observe that issues that are differentially prioritized by women (men) citizens are also differentially prioritized by women (men) MPs. To further examine how the size and substance of these gender gaps at both the citizen and MP levels are related to each other, we now examine the correlation of gender gaps between citizens and MPs. To understand this quantity 


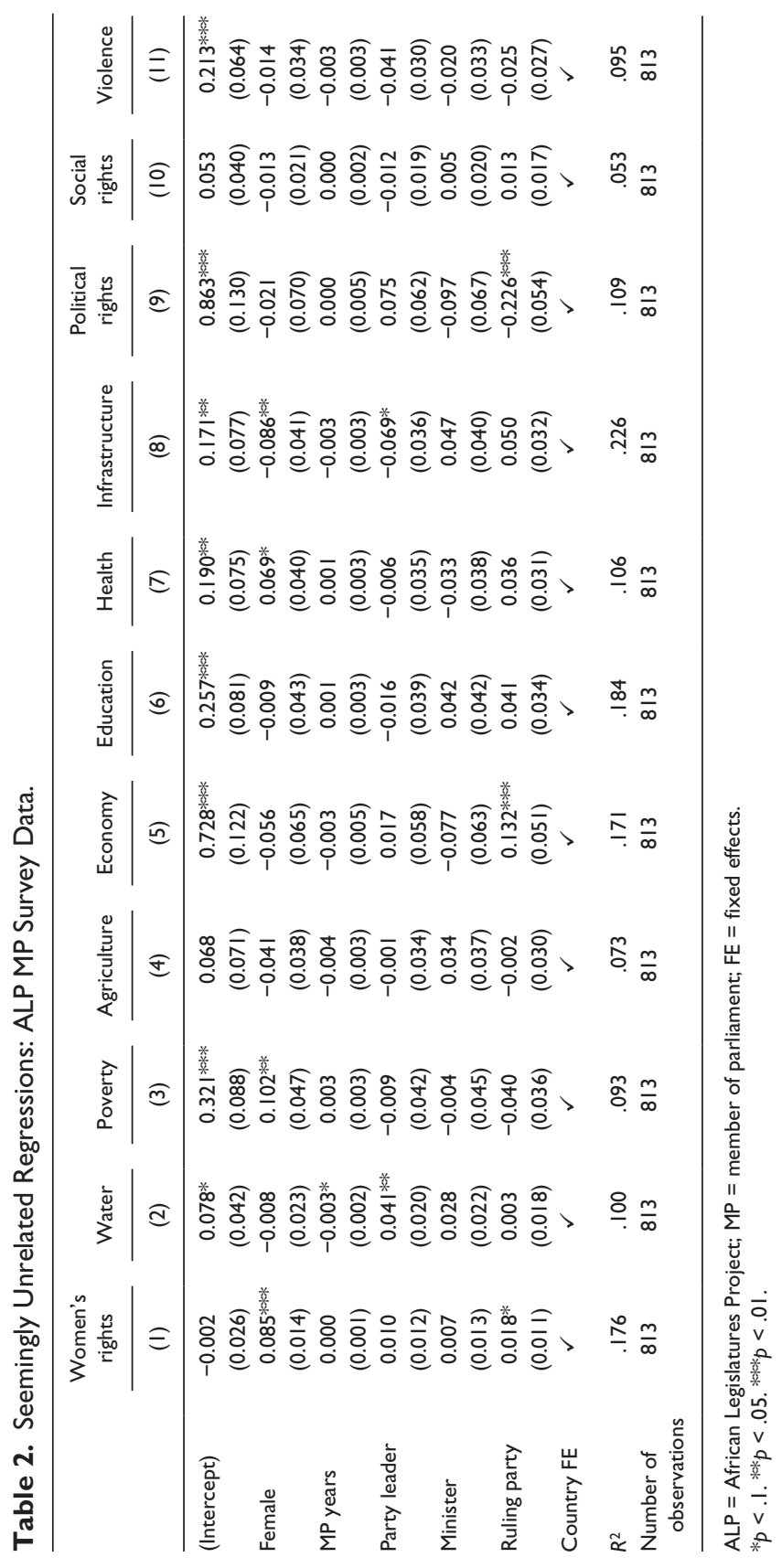




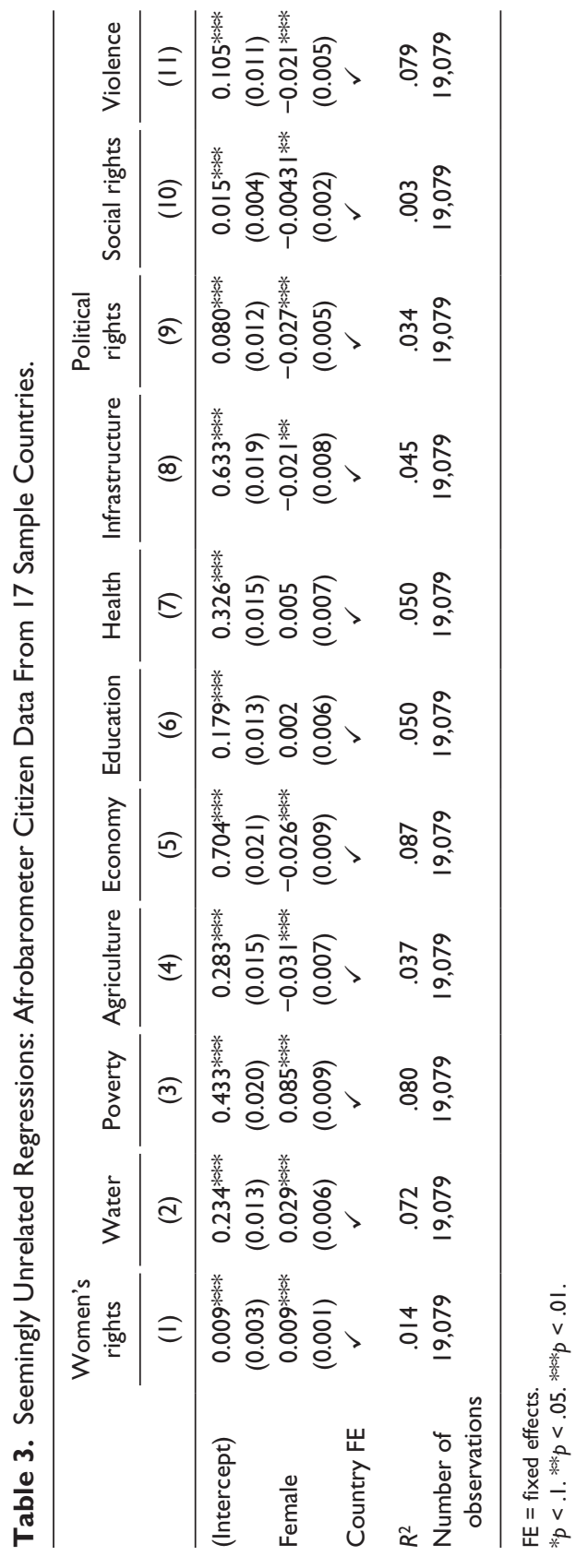


of interest, consider the following example: In our data, $60.2 \%$ of women citizens claim that poverty is one of the three most important issues their government should address, whereas $51.8 \%$ of men citizens do so. The gender gap, then, at the citizen level is 9.5 percentage points. Among legislators in our sample, $45.8 \%$ of women MPs claim poverty is one of the three most important issues the government should address, whereas only $35.1 \%$ of men MPs do so. The gender gap among MPs, then, is 10.7 percentage points (see Table 1).

Our calculation of interest reveals how strongly the gender gaps - that is, 9.5 compared with 10.7-are correlated across issue areas. Above, we presented correlations between prioritization levels of men and women MPs and their cogender constituents separately, but this did not take into account whether issues were generally salient or a gender-specific priority. Examining the correlation between gender gaps at the citizen and MPs levels allows us to identify how gender differences in issue prioritization are related between citizens and MPs while taking into account that certain issues are generally more prioritized. The calculated correlation in gender gaps is quite high: $r=$ $.74 .^{8}$ Figure 3 plots the gender gaps at both the MP level and the citizen level. This relationship shows that as issues become increasingly women preferred among citizens, they also become increasingly women preferred among MPs.

Our findings at both the MP and citizen levels reveal gender differences in substantively meaningful policy areas that relate in predictable ways to the divergent social and economic experiences of men and women. For instance, work from other developing contexts indicates that men tend to prioritize infrastructure projects, most notably roads, because they travel more frequently and further from the home than women (Chattopadhyay \& Duo, 2004; Olken, 2010). We find similar results in the Afrobarometer data from our 17-country sample. Men are significantly more likely than women to report that they travel $10 \mathrm{~km}$ or more every day from their homes $(16.9 \% \mathrm{vs}$. $11 \%, p \leq .01)$ and less likely to report that they never leave home (18.4\% vs. $23.7 \%, p \leq .01$ ). Furthermore, work on infrastructure projects is typically completed by male laborers. In contrast, women have clear objective reasons to prioritize women's rights and poverty may be a women-preferred policy area if women typically take on the social role of caretakers (Gottlieb et al., 2016, p. 3).

Above, we theorized that similar gender gaps in MPs' and citizens' priorities may emerge if MPs held similar internally held beliefs as citizens or because MPs are particularly aware of, or responsive to, cogender citizens. For example, men MPs may prioritize infrastructure projects because their own personal experiences lead them to this belief (if men MPs are more likely to have a background in infrastructure-related industries, for instance) 


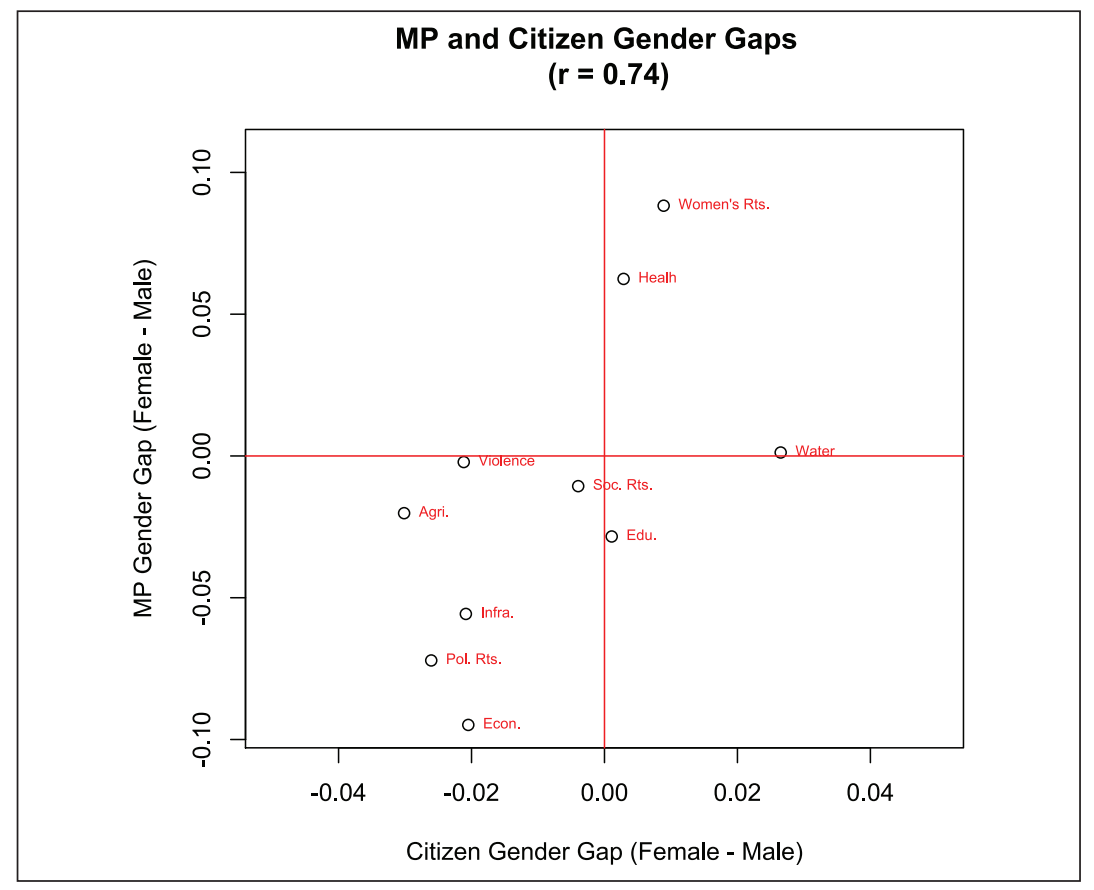

Figure 3. Correlation between MP and citizen gender gaps. $M P=$ member of parliament.

or they may be more in touch with the needs of their men constituents who benefit more, on average, from investments in infrastructure than do women. We cannot distinguish between these two possibilities, but future work could attempt to adjudicate why we see the gendered patterns we do.

\section{Country-Level Variation in Priority Congruence}

Thus far, we have presented results that pool our data across our 17-country sample. This choice is motivated by the limited number of MPs per case $(n \approx$ 50) and, in particular, the limited number of women MPs given women's underrepresentation (ranging $n=1$ to $n=20$ per case). Acknowledging that our sample size is limited, here, we present an initial analysis that examines variation in the convergence of gender gaps in issue prioritization between countries. To take general issue salience into account, here, we maintain our focus on the relationship between gender gaps observed among citizens and among elites. An examination of cross-national variation in the levels of MP 
prioritization to levels expressed by citizens is included in the Online Appendix. Figure 4 replicates Figure 2 to display variation in both MP and citizen gaps by issue for each of the 17 included countries. The country-specific panels indicate that MP/citizen gaps are more aligned in some cases than in others. Indeed, there is substantial variation in country-specific correlations, which range from $r=-.36$ in Mali to $r=.80$ in Kenya. ${ }^{9}$

Although our 17-country sample limits our ability to offer an exhaustive test of possible predictors of the cross-national variation we observe, here, we offer a preliminary and exploratory analysis of several parliamentary features that may affect the extent to which gender gaps between citizens and MPs converge.

\section{Democracy and Multiparty Competition}

Because they are not accountable to constituents in the same way, all MPs in nondemocratic systems likely have less incentive to prioritize issues that citizens value. If both men and women MPs are out of touch with citizens' priorities, there is likely less overall convergence in gender-specific priorities. Authoritarian or hybrid settings may also particularly constrain women MPs. If women representatives, particularly in quota settings, are more loyal to the regime than their male colleagues, we may see that women MPs in particular are less willing or able to express gender-specific priorities in less democratic settings (see Ahikire, 2003; Muriaas \& Wang, 2012; Tamale, 1999, on the Uganda case). This may be exacerbated if women are underrepresented in opposition parties in African parliaments, which appears to be the case. In our sample, $65 \%$ of women MPs belong to the ruling party, whereas only $56 \%$ of men MPs do (Online Appendix Table A2). Although not the focus of this study, our ALP survey data also reveal that women MPs are significantly less likely to act in ways that go counter to the wishes of their party, such as voting across party lines or opposing the party's position, again suggesting that legislatures with dominant ruling parties may particularly attenuate women MPs' desire or ability to express gender-specific priorities. In the models that follow, we measure political openness through a country's Polity IV democracy score, which measures constraints on executive authority and the openness of political competition.

The number and strength of political parties also may be a particularly important feature of democratic politics in explaining gender-specific priority convergence. As the size and strength of opposition parties increase, the likelihood that parties will recruit candidates with programmatic policy priorities also increases (a trend that may be particularly true in proportional representation systems with party lists). Alternatively, party systems dominated by one 


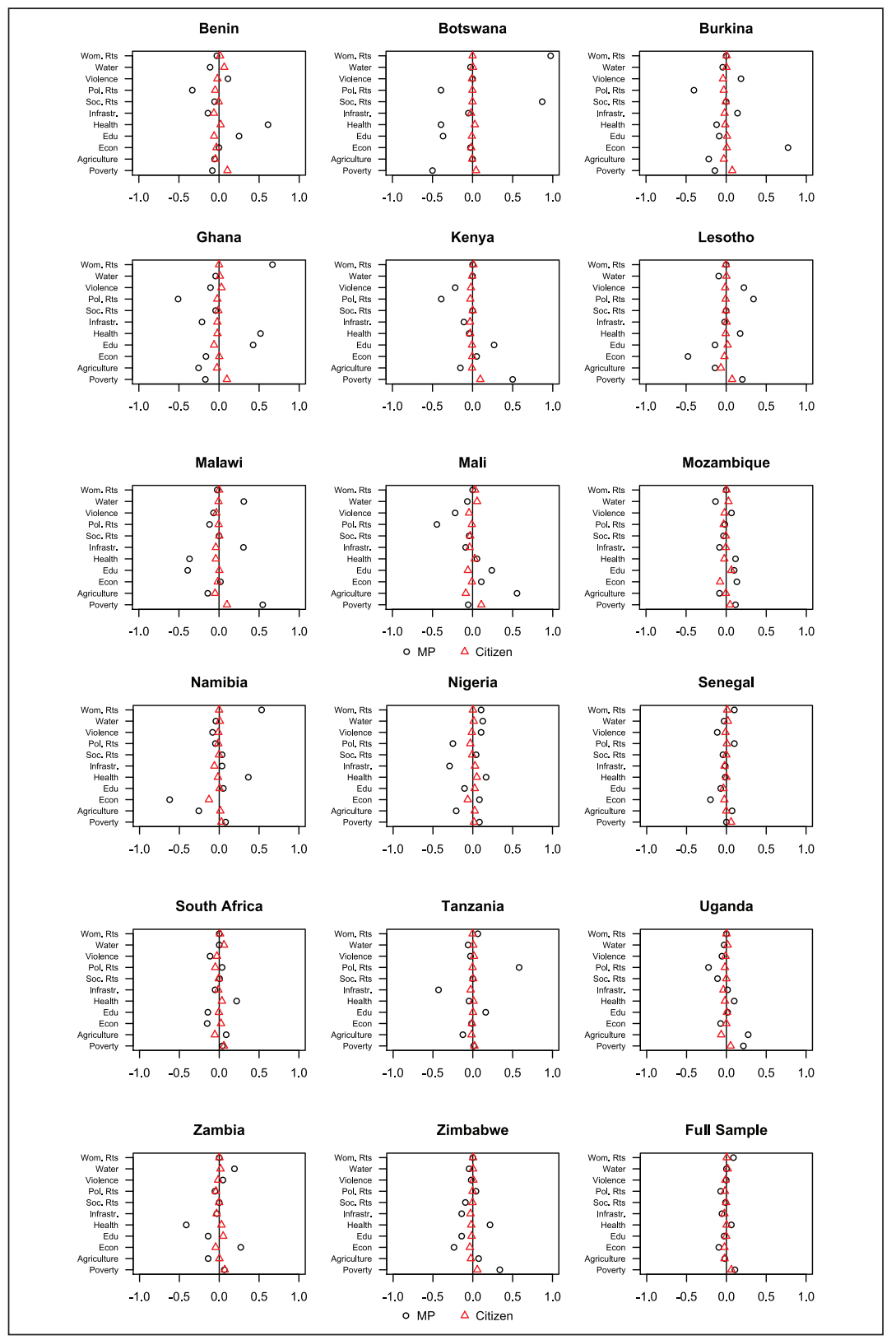

Figure 4. Country-level variation in gender gaps among both MPs and citizens. $\mathrm{MP}=$ member of parliament. 
Table 4. OLS Models Predicting Country-Level Correlations in MP/Citizen Gender Gaps.

\begin{tabular}{lcccc}
\hline & Model I & Model 2 & Model 3 & Model 4 \\
\hline (Intercept) & 0.237 & $1.468^{* *}$ & 0.036 & 0.353 \\
& $(0.825)$ & $(0.744)$ & $(0.764)$ & $(0.764)$ \\
$\log$ (GDP per capita) & -0.018 & -0.158 & -0.142 & -0.056 \\
& $(0.135)$ & $(0.112)$ & $(0.115)$ & $(0.142)$ \\
\% Women in parliament & 0.003 & 0.012 & 0.015 & 0.014 \\
& $(0.011)$ & $(0.009)$ & $(0.009)$ & $(0.016)$ \\
Polity IV & & $0.061^{* *}$ & $0.046^{*}$ & \\
& & $(0.022)$ & $(0.023)$ & \\
\% Ruling party seat share & & $-1.297^{*}$ & & \\
& & $(0.643)$ & & \\
Effective number of parties & & & $0.232^{*}$ & \\
& & & $(0.126)$ & \\
Gender quota & & & & -0.313 \\
& & & & $(0.339)$ \\
$R^{2}$ & .006 & .544 & .519 & .084 \\
Number of observations & 14 & 14 & 14 & 14 \\
RMSE & 0.395 & 0.296 & 0.304 & 0.398 \\
\hline
\end{tabular}

OLS = ordinary least squares; $M P=$ member of parliament; RMSE = root mean square error. $*_{p}<.1 . *_{p}<.05$. $* * * *_{p}<.01$.

ruling party — even in otherwise democratic states (e.g., Namibia, Botswana)— may have less electoral pressure to represent citizens' political priorities, including gender-specific priorities.

We measure multiparty competition in two ways-first as the percentage of parliamentary seats held by the ruling party and second through the country's effective number of political parties with parliamentary representation. We take as our dependent variable the country-level correlations of gender gaps described above. Higher values of our dependent variable indicate that MPs' and citizens' priorities are more closely aligned by gender. We include logged GDP per capita as a control for varying levels of economic development across models. We exclude the three cases in which women's representation is very low (below $8 \%$ ), which leads to extreme MP gaps. For instance, in the indicative case of Botswana, one woman MP was surveyed and because she listed women's rights as a top priority, the observed gap is close to 1 . We present these results in Table 4 below.

Despite the low sample size, both a country's Polity IV score and the percentage of seats held by the opposition reach or approach traditional 


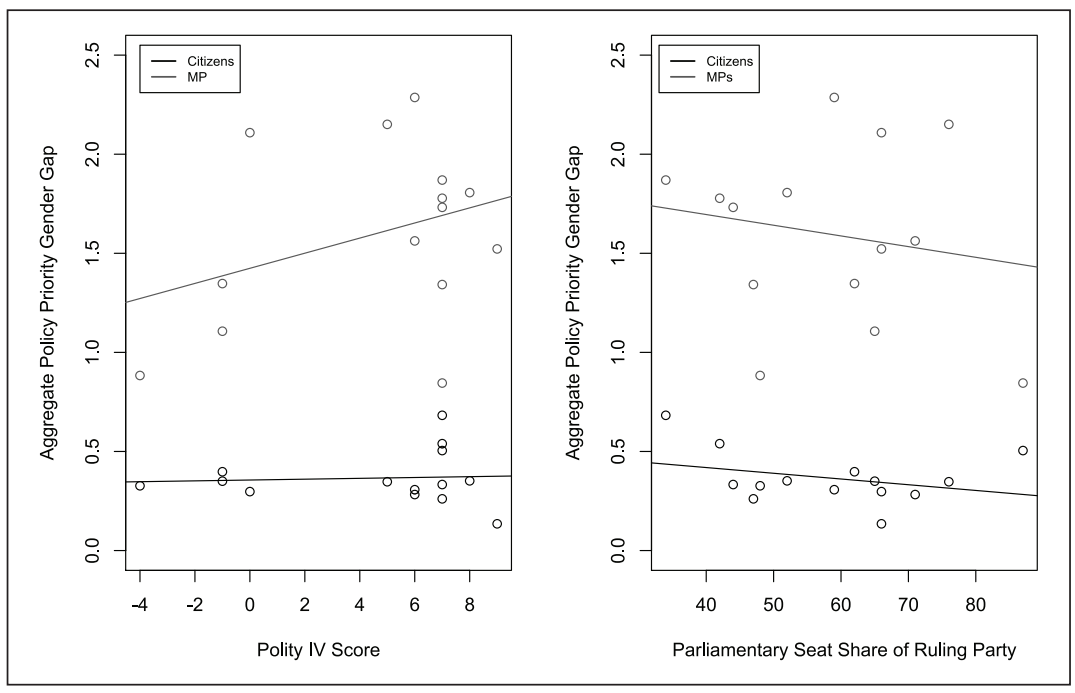

Figure 5. Aggregate gender gaps by level of democratic openness.

significance levels (Polity IV at $p \leq .05$ and ruling party seat share at $p \leq .10$ ). When we operationalize multiparty competition as the number of effective parties, the variable also approaches traditional statistical significance despite the low sample size $(p \leq .10) .{ }^{10}$ Model fit is also relatively high when we include measures of democracy and multiparty competition $\left(R^{2}=.5\right)$. Substantively, moving from one standard deviation below the mean Polity score to one standard deviation above the mean (moving from a score of 1 to a score of 8.9), moves the associated correlation in gaps from essentially nonexistent $(r=-.01)$ to substantial $(r=.36)$. We see a similar magnitude associated with ruling party seat share. Moving from one standard deviation above the mean to one standard deviation below the mean (from the ruling party controlling $75.3 \%$ of seats to $48.7 \%$ of seats) moves the correlation again from nonexistent $(r=.01)$ to substantial $(r=.34)$.

The correlation in gender gaps that we observe in more democratic states could indicate that citizens express more gender-specific priorities in these countries, that representatives do, or that both groups are more likely to do so. We examine our data to determine which of these explanations has the most power. Figure 5 plots the aggregate gender gaps for citizens and MPs along two of our key democracy measures: Polity IV score and ruling party parliamentary seat share. For both MPs and citizens, we calculate the aggregate gender gap by summing the absolute difference between the share of men and 
women who prioritize each issue area. ${ }^{11}$ Larger values indicate that men and women have more distinct priorities.

Figure 5 indicates that gender gaps among citizens remain fairly constant across regime, although we see that citizen gender gaps become slightly less pronounced as ruling parties gain dominance. Gender gaps among MPs are more responsive to regime characteristics. They become significantly less pronounced as countries become more one-party dominant and increase substantially as a country's Polity IV score increases. In sum, MPs are more likely to express gender-specific priorities as their countries become more democratic and more open to multiparty competition, and this movement is likely driving the country-level convergence of gender gaps revealed in Table 4.

\section{Additional Explanations: Women's Numeric Presence and Electoral Gender Quotas}

We include two additional country-level variables that previous literatures suggest may explain the observed variation in cross-national priority congruence. First, we include women's parliamentary seat share. As women's numbers in representative bodies increase, so may the heterogeneity of views that are represented, be they regionally specific or based on other identity cleavages, such as class, religion, age, or ethnicity (Alidou, 2013; Hughes, 2011). When their numbers are few, women MPs will find it difficult to aggregate the diverse priorities of women citizens and may also face constraints imposed by working in male-dominated institutions. Accordingly, we test whether women's parliamentary presence (percent of seats held in a single or lower house) predicts the cross-national variation we observe.

Second, we include the presence of an electoral gender quota, although our expectations here are mixed. Research from African cases suggests quotas may increase women's substantive representation (Disney, 2006; Walsh, 2012a), may serve to decrease democratic representation in general (Longman, 2006; Muriaas \& Wang, 2012), or may have no effect distinguishable from the presence of nonquota elected women (Clayton et al., 2017). Table 4 reveals that both these parliamentary features - women's descriptive representation and the presence of a gender quota - are not significant predictors of priority congruence. It appears that whether MPs express genderspecific priorities is neither a feature of the number of women in parliament nor a feature of how women are elected.

\section{Conclusion: Gender and Priority Representation}

Globally, women's parliamentary representation has doubled in the last 20 years. This development has transformed African parliaments, and the region 
now boasts legislatures with some of the highest levels of women's representation in the world. Women's rising numbers have prompted both public and scholarly interest around their possible legislative consequences. Indeed, one of the fundamental claims that practitioners and scholars have leveraged to justify the need for more women in decision-making bodies is the idea that women bring unique priorities to office and represent historically marginalized citizens. Our work lends support to this claim. We find that women and men MPs hold different legislative priorities that map onto citizens' genderspecific concerns. We find these gendered patterns of substantive representation are strongest when legislative institutions impose executive restraints and allow for open and competitive elections.

Our findings speak to several aspects of the representative process. First, we find convergence of gender-specific priorities when we examine differences between men and women, but not when we examine absolute levels of political prioritization. Legislators and citizens generally prioritize the same issues because certain policy domains are generally more pressing than others. For example, in our data, more than two thirds of both MPs and citizens list the economy as one the most important issues facing their countries, whereas less than $5 \%$ of MPs and less than $2 \%$ of citizens list social rights (such as reducing discrimination and inequality) as a top government priority. Differences in political priorities, then, indicate how men and women MPs represent issues at the margins, after taking into account needs relevant to all citizens. Put in another way, we find that men and women legislators express gender-specific priorities in addition to citizens' general concerns.

Second, the policy areas where we find gender differences are substantively revealing. We find that women MPs articulate women's rights as one of the most pressing political issues in their countries, much more so than their male colleagues and, indeed, significantly more so than women citizens. This suggests that the most fundamental claim related to women's substantive representation is occurring: Women representatives articulate a desire to act in the interest of women. This is in line with several studies from African legislatures demonstrating the role women MPs have played in securing legislative gains for women, such as laws combatting domestic violence and rape and laws improving women's status under family law (see, for example, Bauer, 2012; Disney, 2006; Meintjes, 2003).

The other policy domains where we find differences are also interesting. Similar to the studies from Western and Latin American cases, we find that women MPs and citizens prioritize poverty alleviation (Norris, 1996; Schwindt-Bayer, 2006). That this finding is so consistent across incredibly diverse cases - and emerges among politically elite women who themselves are less exposed to personal poverty - points to an unanswered question in the gender and politics literature: Why is poverty a woman's issue? We hope 
future research can tackle this question directly and move beyond claims that might essentialize women's preferences.

There are two areas where we see gender gaps at one level but not the other. First, we find that women citizens give great priority to the provision of potable water, but that this is not an area of particular political importance to women (or men) MPs. This likely speaks to class differences between MPs and constituents. Fetching water for the family is women's work across Africa, as in most poor countries globally. Women MPs, however, typically from elite backgrounds, likely have not experienced this role in household labor. Furthermore, women (and men) MPs may not see access to water as a political issue, whereas their women constituents do. Women's organizations in civil society may be well positioned to strengthen lines of communication between rural women and women MPs on this issue.

Second, we find that women MPs prioritize health more than men MPs, whereas there are no differences among citizens. Our finding that health is a domain prioritized by women legislators is consistent with previous studies on MP priorities (Norris, 1996; Schwindt-Bayer, 2006; Tremblay, 1998; Wängnerud, 2000) and aligns with recent work suggesting that women's increased presence in legislative bodies leads to more public spending on health (Clayton \& Zetterberg, in press) and better public health outcomes (Bhalotra \& Clots-Figueras, 2014; Swiss et al., 2012; Westfall \& Chantiles, 2016). Why we observe this trend - especially when, at least among African cases, it is not observed among citizens-is puzzling. It is possible that health is a feminized policy area, one that comports with gender norms around women's role as caregivers, and, thus, women representatives are able to claim this domain when traditionally masculine policy domains (e.g., defense, finance) are already claimed by men (cf. Schwindt-Bayer, 2006).

Our findings add to the emerging consensus in the literature that a representative's gender informs her policy priorities. Our cases are home to more than half of sub-Saharan Africa's population, and our work, thus, contributes considerable geographic scope to previous research. In Africa, citizens' political priorities generally reflect their first-order needs, such as those addressing poverty and health concerns. Whereas, citizens and MPs in richer countries are more likely to list issues less directly related to their immediate welfare. Wängnerud (2000), for instance, finds that the environment is one the most commonly listed top priorities by Swedish citizens, both men and women (p. 73). That gendered patterns of interest representation occur even where politicians are governing predominately poor and rural citizens suggests that gender fundamentally shapes political priorities in ways that relate to citizens' daily welfare. 
We find considerable cross-national variation in the convergence of MPs' and citizens' gender-specific priorities. Although not our focus here, this finding may have consequences on the symbolic effects of women's representation. Women's presence has increased dramatically across both democratic (e.g., Senegal, South Africa) and nondemocratic or hybrid regimes across the continent (e.g., Rwanda, Zimbabwe). If women are viewed as not substantively representing women's priorities in less democratic parliaments, the symbolic effects of their presence may be weakened. This may explain why African-based studies examining the effects of women's representation on women citizens' political engagement have produced contradicting results (Barnes \& Burchard, 2013; Clayton, 2015). What women do in representative bodies may affect their symbolic power.

Finally, our work provides robust empirical support to one of the central claims made by scholars of gender and politics: that women are better situated to represent women citizens because they more accurately reflect their political priorities. We theorize this is the first step in the classic question of whether "women act for women." In this regard, our work follows the conceptual framework laid out by Goetz (2003), who notes that when asking this question, scholars must consider whether women are both willing and able to act for women. We have found evidence of the former, but have not addressed the latter. Many scholars have documented the ways that women may be prohibited from acting on their priorities through both formal and informal legislative institutions. Related to formal exclusion, women may be assigned less important ministerial or committee positions (Barnes, 2016; EscobarLemmon \& Taylor-Robinson, 2016; Heath, Schwindt-Bayer, \& TaylorRobinson, 2005; Krook \& O'Brien, 2012). Related to informal exclusion, women may be ignored during policy debates (Clayton, Josefsson, \& Wang, 2014), compelled to work in areas that conform to gender stereotypes (Schwindt-Bayer, 2006), or pressured by their parties to toe the party line (Cowley \& Childs, 2003; Muriaas \& Wang, 2012). Mapping exactly where in the representative process women's priorities are sidelined is key to scholars interested in the process of substantive representation. Here, we have argued that a first step in this process is assessing whether and when women desire to act for women - and we hope future work will build on these findings to further understand how women's interests, priorities, and preferences are manifested in the representative process.

\section{Acknowledgments}

We are grateful for insightful feedback from Cindy Kam, Liz Zechmeister, Brenton Kenkel, Hye Young You, Diana O'Brien, Michelle Taylor-Robinson, Nahomi Ichino, Maria Escobar-Lemmon, Lisa Baldez, Kristin Michelitch participants at the 
Conference on Women's Political Representation and Leadership at NYU Abu Dhabi, the Politics of Gender and Sexuality in African Symposium at Yale University, the 2015 Midwest Group in African Political Economy (MGAPE) meeting at Vanderbilt University, and the 2016 African Studies Association Annual Meeting.

\section{Declaration of Conflicting Interests}

The authors declared no potential conflicts of interest with respect to the research, authorship, and/or publication of this article.

\section{Funding}

The authors disclosed receipt of the following financial support for the research, authorship, and/or publication of this article: Fieldwork for the African Legislatures Project was supported by grants from the World Bank, the United Kingdom Department for International Development, the United States Agency for International Development, the Vice Chancellor's Fund at University of Cape Town, the Heinrich Boll Stiftung, PACT/Zambia, and the Calouste Gulbenkian Foundation. Other research activities were supported by the Harry Oppenheimer Institute, the center for Higher Education Transformation, the South African National Research Foundation, the Andrew Mellon Foundation, and the Center for Democratic Governance and Leadership at Bridgewater State University.

\section{ORCID iD}

Cecilia Josefsson (iD https://orcid.org/0000-0003-3240-7019

\section{Notes}

1. Members of parliament (MPs') priorities may affect how ministerial bills are debated and which pieces are ultimately passed. An MP's priorities may also influence her lobbying efforts and use of national- and constituency-level funding.

2. Surveys were conducted through face-to-face interviews. The response rates were very high for elite surveys, averaging $80 \%$ across the 17 countries. There was no statistical difference between the response rates of men and women MPs. The Online Appendix contains further information on survey collection and MP sampling procedures.

3. We examine issue salience rather than general ideological positioning or preferences within particular issue areas. This allows us to observe which sorts of political issues are prioritized before the task of assessing ideological preferences within issues, which may vary by respondent interpretation and national context (Zechmeister \& Corral, 2013).

4. Women MPs - correlation with women citizens: $r=.77$, and correlation with men citizens: $r=.74$. Men MPs - correlation with men citizens: $r=.72$, and correlation with women citizens: $r=.71$. 
5. When we use the fifth round of Afrobarometer survey data collected between 2011 and 2013, we observe similar gender differences in priorities.

6. These values are coded dichotomously to indicate whether an MP raised the issue or not. We model this quantity as linear for ease of interpretation and comparison with the citizen data, but our results are robust to a binomial logit specification.

7. On two separate African Legislatures Project (ALP) survey questions, we also find that women MPs are significantly more likely than their male colleagues to think their governments are doing poorly on issues related to women's rights and that government policies have not improved substantially in recent years.

8. We find a correlation of $r=.69$ when only including the subset of relatively well-off citizens (calculated through a needs-based poverty index), a correlation of $r=.82$ among the subset of urban citizens, and a correlation of $r=.71$ among employed citizens. It seems, then, various dimensions of class are not strong mediators of gender gap congruence - but future work might more rigorously test this claim.

9. Because we have a limited sample size of female MPs in each country — on average 8.5 per country - the country-specific correlations tend to be much smaller than the aggregate correlation of $r=.76$.

10. These variables lose traditional significance when also including the cases with low women's representation, either reflecting the extreme nature of the MP gender gaps in these cases or suggesting that democracy and ruling party seat share are only meaningful after women have achieved at least minimal parliamentary representation.

11. To correspond with the analysis presented in Table 4, we again remove the three cases in which women's parliamentary representation is very low resulting in extreme gender gaps - but the patterns we observe remain, and are actually strengthened, when we include the remaining three cases.

\section{References}

Ahikire, J. (2003). Gender equity and local democracy in contemporary Uganda: Addressing the challenge of women's political effectiveness in local government. In A. M. Goetz \& S. Hassim (Eds.), No shortcuts to power: African women in politics and policy making (pp. 213-239). London, England: Zed Books.

Alidou, O. D. (2013). Muslim women in postcolonial Kenya: Leadership, representation, and social change. Madison: University of Wisconsin Press.

Atanga, L. L. (2010). Gender, discourse and power in the Cameroonian parliament. Oxford, UK: African Books Collective.

Barkan, J. D. (2009). Legislative power in emerging African democracies. Boulder, CO: Lynne Rienner.

Barkan, J. D., Mattes, R., Mozaffar, S., \& Smiddy, K. (2010). The African legislatures project: First findings (CSSR Working Paper No. 277). Cape Town, South Africa: Centre for Social Science Research.

Barnes, T. D. (2016). Gendering legislative behavior. New York, NY: Cambridge University Press. 
Barnes, T. D., \& Burchard, S. M. (2013). "Engendering" politics: The impact of descriptive representation on women's political engagement in Sub-Saharan Africa. Comparative Political Studies, 46, 767-790.

Bauer, G. (2012). "Let there be a balance": Women in African parliaments. Political Studies Review, 10, 370-384.

Bauer, G., \& Britton, H. E. (2006). Women in African parliaments. Boulder, CO: Lynne Rienner.

Beckwith, K. (2014). Plotting the path from one to the other: Women's interests and political representation. In M. C. Escobar-Lemmon \& M. M. TaylorRobinson (Eds.), Representation: The case of women (pp. 19-40). Oxford University Press.

Bhalotra, S., \& Clots-Figueras, I. (2014). Health and the political agency of women. American Economic Journal: Economic Policy, 6, 164-197.

Campbell, R., Childs, S., \& Lovenduski, J. (2010). Do women need women representatives? British Journal of Political Science, 40, 171-194.

Celis, K., \& Childs, S. (2012). The substantive representation of women: What to do with conservative claims? Political Studies, 60, 213-225.

Celis, K., Childs, S., Kantola, J., \& Krook, M. L. (2008). Rethinking women's substantive representation. Representation, 44, 99-110.

Chattopadhyay, R., \& Duo, E. (2004). Women as policy makers: Evidence from a randomized policy experiment in India. Econometrica, 72, 1409-1443.

Childs, S. (2002). Hitting the target: Are labour women MPs "acting for" women? Parliamentary Affairs, 55, 143-153.

Clayton, A. (2015). Women's political engagement under quota-mandated female representation: Evidence from a randomized policy experiment. Comparative Political Studies, 48, 333-369.

Clayton, A., Josefsson, C., \& Wang, V. (2014). Present without presence? Gender, quotas and debate recognition in the Ugandan parliament. Representation, 50, 379-392.

Clayton, A., Josefsson, C., \& Wang, V. (2017). Quotas and women's substantive representation: Evidence from a content analysis of Ugandan plenary debates. Politics \& Gender, 13, 276-304.

Clayton, A., \& Zetterberg, P. (in press). Quota shocks: Electoral gender quotas and government spending priorities worldwide. Journal of Politics.

Cowley, P., \& Childs, S. (2003). Too spineless to rebel? New labour's women MPs. British Journal of Political Science, 33, 345-365.

Disney, J. L. (2006). Mozambique: Empowering women through family law. In H. Britton \& G. Bauer (Eds.), Women in African parliaments (pp. 31-57). Boulder, CO: Lynne Rienner.

Downs, A. (1957). An economic theory of political action in a democracy. Journal of Political Economy, 65, 135-150.

Escobar-Lemmon, M. C., \& Taylor-Robinson, M. M. (2016). Women in presidential cabinets: Power players or abundant tokens? New York, NY: Oxford University Press. 
Franceschet, S., Krook, M. L., \& Piscopo, J. M. (2012). The impact of gender quotas. Oxford, UK: Oxford University Press.

Franceschet, S., \& Piscopo, J. M. (2008). Gender quotas and women's substantive representation: Lessons from Argentina. Politics \& Gender, 4, 393-425.

Goetz, A.-M. (2003). Women's political effectiveness: A conceptual framework. In A. M. Goetz \& S. Hassim (Eds.), No shortcuts to power: African women in politics and policy making (pp. 29-80). London, England: Zed Books.

Goetz, A.-M., \& Hassim, S. (2003). No shortcuts to power: African women in politics and policy making (Vol. 3). London, England: Zed Books.

Gottlieb, J., Grossman, G., \& Robinson, A. L. (2016). Do men and women have different policy preferences in Africa? Determinants and implications of gender gaps in policy prioritization. British Journal of Political Science, 1-26.

Griffin, J. D., Newman, B., \& Wolbrecht, C. (2012). A gender gap in policy representation in the US Congress? Legislative Studies Quarterly, 37, 35-66.

Heath, R., Schwindt-Bayer, L. A., \& Taylor-Robinson, M. M. (2005). Women on the sidelines: Women's representation on committees in Latin American legislatures. American Journal of Political Science, 49, 420-436.

Hughes, M. M. (2011). Intersectionality, quotas, and minority women's political representation worldwide. American Political Science Review, 105, 604-620.

Ichino, N., \& Nathan, N. L. (2013). Crossing the line: Local ethnic geography and voting in Ghana. American Political Science Review, 107, 344-361.

International IDEA. (2017). Atlas of electoral gender quotas. Stockholm, Sweden: International IDEA (Institute for Democracy and Electoral Assistance).

Jones, B. D., \& Baumgartner, F. R. (2004). Representation and agenda setting. Policy Studies Journal, 32, 1-24.

Kang, A. J. (2015). Bargaining for women's rights: Activism in an aspiring Muslim democracy. Minneapolis: University of Minnesota Press.

Kerevel, Y. P., \& Atkeson, L. R. (2013). Explaining the marginalization of women in legislative institutions. The Journal of Politics, 75, 980-992.

Krook, M. L., \& O'Brien, D. Z. (2012). All the president's men? The appointment of female cabinet ministers worldwide. The Journal of Politics, 74(3), 840-855.

Longman, T. (2006). Rwanda: Achieving equality or serving an authoritarian state? In H. Britton \& G. Bauer (Eds.), Women in African parliaments (pp. 133-150). Boulder, CO: Lynne Rienner.

Lovenduski, J., \& Norris, P. (2003). Westminster women: The politics of presence. Political Studies, 51, 84-102.

Mansbridge, J. (1999). Should Blacks represent Blacks and women represent women? A contingent "yes." Journal of Politics, 61, 628-657.

Mansbridge, J. (2011). Clarifying the concept of representation. American Political Science Review, 105, 621-630.

Meintjes, S. (2003). The politics of engagement: Women transforming the policy process-domestic violence legislation in South Africa. In A. M. Goetz \& S. Hassim (Eds.), No shortcuts to power: African women in politics and policy making (pp. 140-159). London, England: Zed Books. 
Miller, G. (2008). Women's suffrage, political responsiveness, and child survival in American history. The Quarterly Journal of Economics, 123, 1287-1327.

Muriaas, R. L., \& Wang, V. (2012). Executive dominance and the politics of quota representation in Uganda. The Journal of Modern African Studies, 50, 309-338.

Murray, R. (2014). Quotas for men: Reframing gender quotas as a means of improving representation for all. American Political Science Review, 108, 520-532.

Norris, P. (1996). Women politicians: Transforming Westminster? Parliamentary Affairs, 49, 89-103.

Olken, B. A. (2010). Direct democracy and local public goods: Evidence from a field experiment in Indonesia. American Political Science Review, 104, 243-267.

Phillips, A. (1995). The politics of presence. New York, NY: Oxford University Press.

Posner, D. N. (2005). Institutions and ethnic politics in Africa. New York, NY: Cambridge University Press.

Schwindt-Bayer, L. A. (2006). Still supermadres? Gender and the policy priorities of Latin American legislators. American Journal of Political Science, 50, 570-585.

Swers, M. (2002). The difference women make: The policy impact of women in Congress. Chicago, IL: The University of Chicago Press.

Swiss, L., Fallon, K. M., \& Burgos, G. (2012). Does critical mass matter? Women's political representation and child health in developing countries. Social Forces, 91, 531-558.

Tamale, S. (1999). When hens begin to crow: Gender and parliamentary politics in Uganda. Boulder, CO: Westview Press.

Taylor-Robinson, M. M., \& Heath, R. M. (2003). Do women legislators have different policy priorities than their male colleagues? A critical case test. Women \& Politics, 24, 77-101.

Thomas, M. A., \& Sissokho, O. (2005). Liaison legislature: The role of the National Assembly in Senegal. The Journal of Modern African Studies, 43, 97-117.

Tremblay, M. (1998). Do female MPs substantively represent women? A study of legislative behaviour in Canada's 35th Parliament. Canadian Journal of Political Science/Revue canadienne de Science Politique, 31, 435-465.

Tripp, A. M. (2015). Women and power in post-conflict Africa. New York, NY: Cambridge University Press.

Tripp, A. M., Isabel, C., Joy, K., \& Alice, M. (2008). African women's movements. Cambridge, UK: Cambridge University Press.

Walsh, D. M. (2012a). Does the quality of democracy matter for women's rights? Just debate and democratic transition in Chile and South Africa. Comparative Political Studies, 45, 1323-1350.

Walsh, D. M. (2012b). Party centralization and debate conditions in South Africa. In S. Franceschet, M. L. Krook, \& J. M. Piscopo (Eds.), The impact of gender quotas (pp. 119-135). Oxford, UK: Oxford University Press.

Wängnerud, L. (2000). Testing the politics of presence: Women's representation in the Swedish Riksdag. Scandinavian Political Studies, 23, 67-91.

Weissberg, R. (1978). Collective vs. dyadic representation in Congress. American Political Science Review, 72, 535-547. 
Westfall, A., \& Chantiles, C. (2016). The political cure: Gender quotas and women's health. Politics \& Gender, 12, 469-490.

Young, I. M. (2000). Inclusion and democracy. New York, NY: Oxford University Press.

Zechmeister, E. J., \& Corral, M. (2013). Individual and contextual constraints on ideological labels in Latin America. Comparative Political Studies, 46, 675-701.

\section{Author Biographies}

Amanda Clayton is assistant professor of Political Science at Vanderbilt University. Her research focuses on women's political representation with a regional focus in sub-Saharan Africa.

Cecilia Josefsson is a $\mathrm{PhD}$ candidate in political science in the Department of Government at Uppsala University, Sweden. Her research focuses on political institutions and representation from a gender perspective in a wide variation of contexts, including sub-Saharan Africa, Latin America and Scandinavia.

Robert Mattes is professor of Government and Public Policy at the University of Strathclyde, and Honorary Professor at the Institute for Democracy, Citizenship and Public Policy in Africa, at the University of Cape Town. He is a co-founder and Senior Adviser to Afrobarometer, as well as co-Principal Investigator of the African Legislatures Project.

Shaheen Mozaffar is professor of Political Science at Bridgewater State College, United States, and is a co-principal investigator of the African Legislatures Project. 